\title{
VENEREAL DISEASE IN THE BIBLE
}

\section{BY}

\author{
R. R. WILLCOX \\ Senior Assistant Medical Officer, Department of Venereal Diseases, St. Mary's Hospital, London; \\ Physician in Charge, Department of Venereal Diseases, King Edward VII Hospital, Windsor
}

The existence or otherwise of allusions to syphilis in the books of the Old Testament is of more than passing interest to the venereologist, as it is of importance not only in considering arguments for and against the Columbian theory of the American origin of the disease in Europe, but also in the protracted dispute as to whether yaws and syphilis are or are not the same disease or modifications of the same pathological process.

The Columbian theory has had its adherents ever since Frascator gave the name to syphilis in $\mathbf{1 5 3 0 .}$ Of modern writers, Abraham (1936) in Great Britain, and Pusey (1935) in the United States have held essentially this point of view. This argument directs attention to the probable presence of bone syphilis in the skeletons of ancient American Indians, and to the fact that there was a severe, and often fatal, form of the disease which swept through Europe like a storm following the return of Columbus in 1493, and which gained a substantial foothold amongst the troops of both sides at the siege of Naples in 1495. Later, as the army of Charles VII disbanded, syphilis made its appearance in one after another of the European capitals, and was taken further to the Orient by Vasco de Gama in 1498.

Supporters of this argument, finding an absence of evidence of the previous existence of syphilis in Europe or in the Near East, find many supposed Biblical or other possible early allusions unacceptable, and any others that are at all suspicious are discounted as referring to soft sore, lymphogranuloma venereum, or other venereal or dermatological complaints.

Those holding opposite views utilize the syphilisyaws controversy, either by holding that these two diseases are one and the same, as suggested by Butler (1936), and Hudson (1946), who consider that both diseases are caused by $T$. pallidum, or that venereal syphilis has emerged from non-venereal yaws as a result of this organism's fight for survival in the face of improved hygienic and sociological conditions but that now, even today, intermediate forms still exist, as bejel, pinta, and the Australian boomerang leg. It is held that $T$. pallidum has been with us as long as man himself, and that it probably obtained world-wide distribution in the earliest migrations from Africa and much later crossed the Atlantic again in considerable profusion during the long years of the slave trade.

Attention is directed to the facts that the white man during sojourn in the tropics contracts syphilis but never yaws, and that the behaviour of the two diseases is either identical or overlapping in nature ; and it is deduced that the general differences which do exist can be explained on the basis that yaws is an extra-genital infection of childhood, and syphilis a venereal infection of adults. Thus the almost complete absence of congenital forms of yaws is explained. Alleged, but not entirely convincing, differences of the behaviour in the laboratory of strains of organisms taken from patients suffering from these two diseases are discounted by the suggestion that those of syphilis have become slightly modified as a result of centuries of inunctions and injections of curative drugs and that, were they allowed to do so, they would under suitable conditions relapse again into the primitive yaws form.

Ridiculing the idea that a few infected sailors could in the course of a few years syphilize almost the whole of the civilized globe, those holding these views will sometimes go so far as to seek to prove that the boot is indeed on the other foot, for, though syphilis certainly existed on the American continent before Columbus, they state there is little evidence that it actually pertained to the West Indies. One of Columbus' men may have infected the natives who in turn reinfected other members of the ship's crew, and the West Indians were then helpless to avoid taking the blame that was apportioned to them.

That syphilis is not described in ancient literature is also denied, and it is pointed out that treponematosis may have existed in non-venereal forms- 
which would account, therefore, for the suggestion that such a venereal complaint is not lavishly described. It is suggested also that it was often referred to under the vague term "leprosy," and it was not until after the Renaissance, as certain distinct diseases came to be known, that leprosy in Great Britain declined to the point of extinctiona fact that serves to complete the argument.

Thus supporters of the Columbian theory have also to be dualists in the yaws-syphilis controversy, while those champions of American honour are almost automatically unionist.

The old Testament, which is a collection of religious literature, though referring to events of long before, was not actually written at the earliest until the seventh or eighth century B.C., and some items were not composed until the second century B.C. (Moffat, 1926). In studying these writings the Columbians have to discount any supposed references to syphilis, while the unionists have the advantage as they seek positive evidence not only of venereal lues but also of non-venereal treponematosis reminiscent of bejel as found in the Bedouin Arabs today.

\section{Idolatry}

The diseases of the Old Testament, the Pentateuch in particular, have been reviewed by Brim (1936), who also devotes considerable space to idolatry and the various gods of the indigenous tribes of Canaan. He considers that phallic worship was a common feature and that the frequent allusions to pillars. altars, high places, and groves support this. The oft-recurring worship of Baal-Peor, or Baalim, is but one example, and such worship was accompanied by sexual excesses and perversions during which the wearing of attire belonging to the opposite sex was sometimes part of the ritual. (The word ' Baal' in Hebrew, meaning fructifier, is frequently used in matters concerning sexual intercourse.)

While the moral standards of the Egyptians were low, that of the tribes with which the Israelites were to come into contact were no better and, not suprisingly, at the forefront of the Laws of Moses occurred what was to be the First Commandment, concerning just such matters of idolatry. The Israelites were warned against phallic worship and forbidden to make " a graven image, the similitude of any figure, the likeness of male or female" 1 or to " rear up a standing image" ${ }^{2}$ or to go awhoring after the gods of others, ${ }^{34}$ and the donning of clothes of the opposite sex was clearly forbidden. ${ }^{5}$ In later

\footnotetext{
1. Deuteronomy, 4, 16. (All

3. Exodus, 34, 15
4. Judges, 2,17 .

Authorized Version.)

2. Loviticus, 26, 1 .
}

days Jeremiah bemoaned that Israel was playing the harlot upon every high mountain and under every green tree and was committing adultery with stones and stocks. ${ }^{6}$

With the sexual act playing such a prominent part it is to be expected, therefore, that the practice of such idolatry would be followed by retribution in the form of venereal disease. One possible example is afforded by the incident of the golden calf. The wandering Israelites, perhaps not appreciating the austerity which was the price of their freedom from bondage in Egypt, were often muttering and resentful and bordering on mutiny. Such an outburst occurred when Moses had been absent for a considerable time on Mount Sinai and this resulted in the making of a new god. When Moses at last returned it was to witness much singing and dancing in the naked state. ${ }^{7}$ In spite of the blood bath that followed when, to restore order, some three thousand were slain, ${ }^{8}$ this incident was apparently followed by an outbreak of venereal disease for " the Lord plagued the people because they made the calf." ${ }^{9}$

\section{Gonorrhœa}

Whatever may be the views of the correct portrayal or otherwise of syphilis in the Bible, there is no disagreement on the subject of gonorrhœa, which is described as an "issue." While little is said concerning therapeutics, the Mosaic law is very strict in the matter of the public health measures to be taken and of general prophylaxis. Thus the Bible portrays for us the very earliest measures of venereal diseases control.

With sexual promiscuity discouraged, the priests were forbidden to marry a whore and were instructed only to take a virgin to wife. ${ }^{10}$ Sufferers from gonorrhœa were excluded from the tabernacle, ${ }^{11}$ and not only was the patient himself unclean, but also his bed, his garments, and anything he may have sat upon, including his saddle, his sputum and drinking vessels were likewise considered infectious. ${ }^{12}$ Thus today the fears of contraction of gonorrhœa from water-closet seats and the occasional incrimination by the patient of the bicycle as the cause of his urethral discharge may be traced back through the centuries, when the saddle and vessels of earth were considered to be possible agents of infection.

The patient with gonorrhœa was an outcast from the camp for seven days after the discharge had ceased. Following this short period of surveillance

\begin{tabular}{ll}
\hline 6. Jeremiah, 3, 6-9. & 10. Leviticus, 21, 13-14. \\
7. Exodus, 32, 18-25. & 11. Leviticus, 22, 4. \\
8. Exodus, 32, 28. & 12. Leviticus, 15, 2-12. \\
9. Exodus, 32, 35. &
\end{tabular}


after clinical cure, he could then receive atonement by disinfection and the offering in the tabernacle of two turtle doves or two young pigeons. The menstrual flow in the woman was likewise considered unclean and, should intercourse take place at this time, the man was unclean for a week. ${ }^{12}$ It is interesting to observe that coitus during menstruation is still advanced as one of the possible causes of non-specific urethritis. Another occasion for a very temporary quarantine was following a nocturnal seminal emission, although only a bath was necessary to complete a cure ${ }^{14}$ even if the sufferer was still forbidden the camp until the evening. Whenever a clean bill of health was wanting and persons were proclaimed unclean they were not allowed within the camp. ${ }^{15} 16$

\section{Syphilis : Leprosy}

As the term " plague" does not necessarily refer to disease caused by Bacillus pestis, but rather to any large-scale epidemiological misfortune, in the same way "leprosy" throughout the Bible does not always mean true leprosy but covers a whole range of infectious disorders with dermatological manifestations. The question at issue is whether any of these references to leprosy may be held to apply to treponematosis. If so, one would expect to find passages about the framing of the divers laws and ordinances where the terms "issue" and "leprosy" are grouped together.

This expectation is realized in the following phrases: "What man soever of the seed of Aaron is a leper, or hath a running issue ; he shall not eat of the holy things" ${ }^{17}$; "Command the children of Israel that they put out of the camp every leper, and every one that hath an issue "18; and much later David, putting a curse upon Joab for murdering Abner: "Let there not fail from the house of Joab one that hath an issue, or that is a leper. ${ }^{19}$

No man with a blemish or with " a blemish in his eye, or be scurvy or scabbed " might enter the temple. ${ }^{80}$ Anyone with a rising, a bright spot, or scab in the skin of his flesh was instructed to attend the priests for consultation and diagnosis. Ulcerated cases were considered leprous, were isolated for a week, and were then examined again.21 - If by then the scab had spread all over the body, leprosy was diagnosed. "The quick raw flesh in the rising " 28 is taken by some as representing the frambcesiform type of treponematosis. When this turned white, that is when it healed, the patient was considered once again clean.

\begin{tabular}{ll}
\hline 13. Leviticus, $15,24$. & 18. Numbers, $5,2$. \\
14. Leviticus, 15; 16. & 19. I Samuel, $3,29$. \\
15. Deuteronomy, 23, 10. & 20. Leviticus, 21, 20. \\
16. Numbers, $5,2$. & 21. Leviticus, 13, 2-5. \\
17. Leviticus, $22,4$. & 22. Leviticus, 13, 10.
\end{tabular}

"If a man or woman have a plague upon the head or the beard; then the priest shall see the plague : and, behold, if it be in sight deeper than the skin; and there be in it a yellow thin hair; then the priest shall pronounce him unclean; it is a dry scall, even a leprosy upon the head or beard." ${ }^{23}$ This might indicate a secondary syphilitic eruption on the hairline, a circinate syphilide of the face, or more simple diseases such as impetigo contagiosa or sycosis barbæ. It is noted that in mild cases shaving was permitted but not of the affected area. ${ }^{24}$ Later on in the same chapter ${ }^{25}$ it is stated that if there appeared a white reddish sore on the bald head, similar to that on the rest of the skin, then that man was a leper and was utterly unclean (this could well be secondary lues). Such a man was sent out of the camp until he was healed and had to cry "Unclean! Unclean!" at the approach of his fellows. When his sores had healed he was readmitted only after he had bathed seven times, the bathing to include the washing of all clothing and the shaving of all hair. ${ }^{26}$ This suggests that pediculosis may also have been a form of "leprosy."

That some forms of "leprosy" were relatively mild is suggested by the experience of Miriam, Moses' sister, who was unfortunate enough to develop a generalized cutaneous disorder. She was isolated for a week and the whole camp 'waited upon her recovery before moving on. ${ }^{27}$ Elisha, too, cured the Chief of Staff of the Syrian Army by persuading him, rather unwillingly, to sash seven times in the river Jordan. It is clear that the latter had an infectious disease, because a servant of Elisha contracted it after trying to extract payment from the patient for what his master had gratuitously performed. ${ }^{28}$

Just before entering the promised land, Moses reminded the Israelites of Miriam's illness and advised them to take heed of the plague of leprosy and to follow diligently the proscribed laws, Just previous to this he had also warned them against whoredom and sodomy. ${ }^{30}$

\section{Syphilis : The "Egyptian Disease"}

When Moses described the punishments that were likely to ensue upon disobedience of the laws, he said ${ }^{31}$ : "The Lord will smite thee with the botch of Egypt, and with the emerods, and with the scab, and with the itch, whereof thou canst not be healed. The Lord shall smite thee with madness, and blind ness, and astonishment of heart." ${ }^{82}$ " Emerods"

\begin{tabular}{ll}
\hline 23. Leviticus, 13, 29-30. & 28. II Kings, 5, 20-27. \\
24. Leviticus, 13, 33. & 29. Deuteronomy, 24,8-9. \\
25. Leviticus, 13, 42-43. & 30. Deuteronomy, 23, 17. \\
26. Leviticus, 14, 8. & 31. Deuteronomy, 28;27: \\
27. Numbers, 12, 10-16. & 32. Deuteronomy, 28, 28.
\end{tabular}


has always offered translating difficulties. Reference is made in the Psalms ${ }^{33}$ to enemies being "smitten in the hinder parts," and this is supposed by some to mean " hæmorrhoids" ; but it could equally well apply to the condylomata lata of secondary lues. If the first part of the punishment can be made to apply to early syphilis, the madness, blindness, and even astonishment of the heart are surely prophetic of the later manifestations of this disease.

Brim translates this passage as: "You will be smitten with the Egyptian dermatitis, characterized by swellings, dry crusts and ulcers from which you will never be healed." This is elaborated a few verses later ${ }^{34}$ : "The Lord shall smite thee in the knees, and in the legs, with a sore botch that cannot be healed, from the sole of thy foot unto the top of thy head." The suggestion that the rash was irritable or painful is against the idea that it was syphilis, though the cutaneous eruptions of bejel and yaws are sometimes irritating. Even so, syphilis seems to fit the context as well as any other disease. There was a general tendency many centuries later to name the complaint after a neighbour, and it is therefore significant that it was called the " Egyptian disease."

\section{Syphilis : The Plague of Moab}

Thus during the forty years in the wilderness the 600,000 Israelites, living under a virtual military dictatorship, were forced to follow a rigid public health code. In their progress to the land of Canaan the local tribes, not unnaturally, offered some obstruction to their advance. The Edomites forbad passage over their frontiers ${ }^{35}$ and King Arad, the Canaanite, was the first to offer military opposition which, if it had been made in concord with that of other tribes, might have produced a different result. The Canaanites and their cities were utterly destroyed. ${ }^{38}$ The laws of war in those days were, if possible, more brutal than at present. It was decreed for the enemies living outside Canaan that all males should be slain and that their women, cities, and spoils should be taken and enjoyed. Complete extinction was the lot of those actually in the promised land. ${ }^{37}$ Atrocities were also performed. ${ }^{38}$ The Amorites were the next who preferred war to peaceful surrender and they too were defeated and dispossessed, after which the King of Bashan was attacked until none of his subjects were left alive. ${ }^{30}$

When the children of Israel moved onwards and pitched camp on the plains of Moab beside Jericho,

\footnotetext{
33. Psalms, 78, 66

34. Deuteronomy, 28,35

35. Numbers, $20,21.35$.

37. Deuteronomy, 20; 13-17.

38. Judges, 1, 6-7.

39. Numbers, 21, 35 .
}

36. Numbers, $21,3$. the considerable disquiet in the mind of Balak, the Moabite king, can be appreciated. He decided without delay to consult Balaam, and he sent emissaries to him to induce this famous soothsayer and magician to come and give advice on the spot. After some wavering, Balaam was rather reluctantly so persuaded, and in due course he was taken up into the high places of Baal, from which the encamping enemy could be seen. Perhaps impressed by the obviously imposing military strength of the latter, he gave Balak a very poor prognosis ${ }^{40}$-not, however, before earning his large fee by suggesting that, if military means could not ensure a victory, then this result might be achieved if the Israelites could be made to change their God and worship Baal-Peor. ${ }^{41}$

It was not long before the people began to commit whoredom with the daughters of Moab, ${ }^{42}$ and the cult of Baal-Peor assumed considerable popularity. Matters soon got so out of hand that one Zimri, the son of a prominent Simeonite, brought into the camp, within the sight of Moses and the congregation of the tabernacle, a woman named Cozbi, the daughter of a Midianite chief. Aaron's grandson took up a javelin and went to Zimri's tent and impaled them both. That a venereal plague had already broken out is acknowledged in the comment on this deed : "So the plague was stayed from the children of Israel." "4 This is also mentioned in the Psalms."

The plague killed no less than 24,000.45 Its venereal nature was affirmed by Moses ${ }^{\circ}$ and centuries later by St. Paul. ${ }^{47}$

A national service register was then prepared, and one thousand men from each of the tribes were called up to avenge the epidemic. The result was a complete victory, and all captured males were slain, including the five kings of Midian and also Balaam himself, who had tarried too long. The cities were burnt, but the women, children, and goods were saved.

When Moses learnt that the women had been taken captive he was very angry as they had clearly been the direct cause of the previous disaster. He therefore ordered that all male children be killed at once and also all women " that hath known man by lying with him." 48 Of the spoil, all metal objects were sterilized by heat, and materials by disinfectants. ${ }^{40}$ Some 32,000 women were saved by this means. ${ }^{50}$

Thus, after forty years of wandering, the Israelites came to the fringes of the promised land as a strong

\begin{tabular}{ll}
\hline 40. Numbers, 22-24. & 46. Deuteronomy, 4, 3. \\
41. Numbers, 31, 16. & 47. I Corinthians, 10, 8. \\
42. Numbers, 25, 1. & 48. Numbers, 31, 17. \\
43. Numbers, 25, 8. & 49. Numbers; 31, 21-24. \\
44. Psalms, 106, 30. & 50. Numbers, 31, 35.
\end{tabular}


fighting force. The somewhat vicious rules of war were made to obviate the risk of the conquerors falling for the gods of the local inhabitants : a fear that was to some extent justified. Before he died Moses viewed the terrain from Mount Nebo and passed on his leadership to Joshua, who proceeded with the military occupation of the country.

After the Jordan had been crossed, and with the aid of the fifth-column work of Rahab, the harlot, Jericho fell to a war of nerves-not before Joshua had reintroduced the rite of circumcision, observance of which had lapsed somewhat while the Israelites were in the wilderness. That this was thought possibly to have some good effect in the prevention of venereal diseases is indicated by the alleged comment of the Lord: "This day I have rolled away the reproach of Egypt from off you." 51 Before the battle of Jericho, Joshua gave out an instruction against idolatrous practices, "lest ye make yourselves accursed, when ye take of the accursed thing, and make the camp of Israel a curse, and trouble it." "51a This may be taken as a warning against any attempts at the repetition of the events at Moab. After a preliminary siege, Jericho succumbed. The peace terms were harsh : nothing less than total destruction. ${ }^{52}$

Apart from a temporary set back at $\mathrm{Ai}$, the other enemy tribes were conquered and efforts to produce $a^{*}$ united front were either too little or too late. Final victory was utter and complete though, as conquered tribes and nations have always done, the vanquished were later to rise again and trouble the conquerors.

\section{Congenital Syphilis}

No such supposed references to syphilis would be regarded as tenable unless there were also some passages suggestive of the congenital forms of the disease. These are not entirely lacking. The Third Commandment, stating that the iniquity of the fathers would be visited upon the children unto the third and fourth generation is significant, especially as it immediately follows lines forbidding the bowing down to images. ${ }^{58}$ Even if thirdgeneration syphilis is such a rarity, it may be argued that there is no other inherited disease sufficiently common to be preferred, especially as it concerns punishment for possible phallic worship.

Among other deformed, including dwarfs, hunchbacks, and eunuchs, "he that hath a flat nose" was also banned from the tabernacle. ${ }^{\text {s4 }}$ This could be taken to refer either to congenital lues or tertiary forms of treponematosis. Hutchinson's teeth could

51. Joshua, 5, 2-9.

51a. Joshua, $6,18$.

53. Exodus, $20,3$.

52. Joshua, 6, 24. have been meant when, after the Israelites had fallen on hard times, it was written : "The fathers have eaten a sour grape, and the children's teeth are set on edge." ${ }_{55}$ A macerated syphilitic fotus is suggested when Aaron, speaking of Miriam's leprosy, said : "Let her not be as one dead, of whom the flesh is half consumed when he cometh out of his mother's womb. ${ }^{56}$

The protracted results of the plague of Moab were evident in the days of Joshua, of which it is written: "Is the iniquity of Peor too little for us, from which we are not cleansed until this day ?" 57

\section{Syphilis : Job's Illness}

The story cannot be considered complete without passing reference to the Book of Job, especially as Moses has been considered responsible for its content. Job in his illness was full of complaints, but the least that can be said is that treponematosis has to be considered in the differential diagnosis.

"He cleaveth my reins asunder, and doth not spare ; he poureth out my gall upon the ground," 58 might be taken as indicating a genital lesion with perhaps an accompanying broken-down bubo. The possible secondary manifestations which followed included boils from head to toe, ${ }^{50}$ a loathsome skin $^{60}$ which was extremely obstinate in healing ${ }^{61} \mathbf{6 2}$ until it was broken " breach upon breach" and the face was "foul with weeping." 68 Alopecia at the hairline was another feature, ${ }^{64}$ and also severe nocturnal bone pains. ${ }^{65}$ Possible iritis is suggested by failing sight, ${ }^{67}{ }^{68}$ and a foul mouth from mucous patches by his corrupt breath. ${ }^{69} 70$ There were also lack of appetite, ${ }^{71}$ intense wasting, ${ }^{68} 7273$ nocturnal delirium, ${ }^{74}$ insomnia, ${ }^{75}$ dyspnoea, ${ }^{76}$ fever, ${ }^{77}$ diarrhœa, ${ }^{78}$ and abdominal distension : "Behold my belly is as wine which hath no vent; it is ready to burst like new bottles" " which do not entirely fit, though a certain tightness of the collar might be caused by a cervical adenitis. ${ }^{80}$

Whether this disease was syphilis or not, it is not surprising that his wife abhorred him and his friends deserted him. ${ }^{81}$ In any event, which would not have occurred in some of the diseases which might be considered, he recovered, lived to prosper, to

\footnotetext{
55. Jeremiah, 31, 29.

56. Numbers, 12, 12.

57. Joshua, 22, 17.

58. Job, 16, 13 .

59. Job, 2,7

61. Job, 7, 5.

61. Job, 10, 16.

63. Job, 16, 13-16.

64. Job, 19, 9 .

65. Job, 30, 17.

66. Job, 6, 4 .

67. Job, 7, 7 .

68. Job, 17, 7 .
} 
have seven sons and three daughters, and to possess four thousand sheep, six thousand camels, a thousand yoke of oxen, and a thousand she asses. He died old and " full of days." 82

\section{Syphilis : David's Illness}

Finally, it would not be right to conclude without brief mention of David's illness, described by himself in the thirty-eighth psalm. He complained of shooting pains and of wounds which were stinking and corrupt : his loins were filled with a loathsome disease. Iritis is suggested by his failing sight, and his lovers and friends stood aloof from him. Many have alleged that the disease was contracted from the wife of Uriah, and that David himself was well aware that it was the direct result of his sin seems to be shown by the words of the Psalm. ${ }^{83} \mathrm{He}$, too, recovered and lived to a ripe old age. ${ }^{84}$

\section{Summing-Up}

Here, then, is the Biblical evidence. Is there enough to spell syphilis, or at any rate the ravages

82. Job, 42, 12-17.
83. Psaims, 38, 1-i

84. I Chronicles, 29, 28. of $T$. pallidum? If so, the Columbian theory is weakened though an open mind may still be permitted on the yaws-syphilis controversy. Is the evidence inconclusive and the argument too flimsy? In this event the Columbian theory may be retained, though it must at the same time be admitted that syphilis, yaws, bejel, pinta, and the like are separate diseases. This dispute is already centuries old, and in many respects it would be a great pity if someone did produce irrefutable evidence for either side and thus prevent any further such interesting speculation.

\section{REFERENCES}

Abraham, J. J. (1936). Foreword to "Frascator" by Wynne-Finch, H. William Heinemann Medical Books.

Brim, C. J. (1936). " Medicine in the Bible." Froben Press, New York.

Butler, C. S. (1936). " "Syphilis sive Morbus humanus." Science Press, Lancaster, Pa.

Hudson, E. H. (1946). "Treponematosis." Oxford University Press.

Moffat, J. (1926). "A New Translation of the Bible." Hodder and Stoughton, London.

Pusey, W. A. (1935). "The History and Epidemiology of Syphilis." C. C. Thomas, Springfield, Illinois. 